\title{
Introduction to A Research Agenda for Entrepreneurship and Innovation
}

David B. Audretsch, Erik E. Lehmann, and Albert N. Link

Within the span of a generation, innovation and entrepreneurship have emerged as two of the most vital forces in the economy and, even more broadly, in society (Link, 2017). It was not always that way. During the second industrial paradigm, or the era of mass production, particularly following World War II, innovation was barely on the radar screen of economics, management, and other social sciences.

Rather, what mattered for economic performance was articulated concisely by the management scholar, Alfred Chandler (1990), in the title of his seminal analysis of firm competitiveness and productivity - Scale and Scope. Economic success lies in largescale production, which enabled companies to attain the highest levels of efficiency and productivity while reducing average cost to a minimum. The primacy of physical capital as the driving force underlying economic performance was mirrored at the macroeconomic level through the Solow (1956) model. Economic policy reflected the capital-driven economy with its focus on instruments to stimulate investment in physical capital. Innovation played at best a marginal role, which was considerably more than could be said for entrepreneurship. In an economy where scale and scope dictated competitiveness and efficiency, new and small firms were typically viewed as a burden on the economy, and they were characterized as constituting "sub-optimal capacity," meaning that they lacked sufficient scale to be efficient.

All of this changed as the managed economy of mass production eclipsed into decline and something new began to emerge, the third industrial paradigm or the computer era. At the heart of the third industrial paradigm was innovation, where change is the constant. Even as companies, industries, and regions predicated on the factor of production that had driven economic performance in the era of mass production struggled to maintain a positive economic performance, a new factor of production emerged for economic success - knowledge and ideas. As the models of endogenous growth highlighted, not only did knowledge and ideas generate innovative activity, but that knowledge was replete with externalities providing thirdparty firms with the opportunity to leverage new ideas that they did not have to pay for and create themselves. Thus, with the shift from the mass-production economy to the knowledge economy came a commensurate shift away from physical capital towards innovation. 
Spurring innovative activity meant investing in key sources of knowledge and ideas, such as research and development (R\&D) and human capital. However, leaders in business and policy discovered that investments in new knowledge alone did not guarantee the coveted innovative activity. In contrast to the assumption inherent in the models of endogenous growth (Romer, 1986), investment to create new knowledge and ideas was not tantamount to innovation. Rather, a clear gap or hurdle stood between knowledge and innovation. This gap became characterized in the scholarly literature as the knowledge filter, which is defined as barriers impeding the spillover and commercialization of knowledge and ideas preventing them from resulting in innovative activity.

Entrepreneurship emerged as an important remedy to the knowledge filter. By leveraging ideas that otherwise might have remained unutilized and dormant in the incumbent organization that had actually invested in and created that knowledge, entrepreneurship provides the conduit for the spillover of knowledge from the organization creating the knowledge to the new entrepreneurial startup actually commercializing it through innovative activity. Thus, entrepreneurship was found to provide the missing link between investments in new knowledge and the desired but elusive innovations.

The purpose of this book is to highlight new insights and new approaches that might serve to guide research in innovation in entrepreneurship. To accomplish that goal, we have assembled a broad group of accomplished scholars spanning a broad spectrum of research fields and academic disciplines, spanning economics, management, public policy, and finance. The style and focus of each of the chapters reflect the expertise and research field underlying the individual author or team of authors.

The book begins in the following chapter with a seminal contribution by Cristiano Antonelli that has its roots in the fundamental thinking about entrepreneurship and innovation, "Schumpeterian Growth Regimes." From this theoretical basis, Chapter 3 provides a more pragmatic but essential examination of "Measuring Entrepreneurial Impact through Alumni Impact Surveys," by Shiri Breznitz, Brendan Hills, and Qiantao Zhang.

In Chapter 4, Alice Civera, Michele Meoli, and Silvio Vismara consider, "Academic Entrepreneurship: Between Myth and Reality." In Chapter 5, James Cunningham analyzes the entrepreneurial context of scientific research in "Principal Investigators and Boundary Spanning Entrepreneurial Opportunity Recognition: A Conceptual Framework." The spatial dimension of innovation and entrepreneurship is the focal point for Michael Fritsch in Chapter 6, "The Regional Emergence of Innovative Start-ups: A Research Agenda." A research agenda for a very different context, public policy, is posited by Heike Grimm in Chapter 7, "Public and Policy Entrepreneurship Research: A Synthesis of the Literature and Future Perspectives." 
The role of the university in entrepreneurship is the focus of Maribel Guerrero and David Urbano in Chapter 8, "A Research Agenda for Entrepreneurship and Innovation: The Role of Entrepreneurial Universities." A different perspective, corporate entrepreneurship, is provided in Chapter 9, "Corporate Governance and Innovation," by Hezun Li, Timurs Umans, and Siri Terjesen. In Chapter 10, Simon Mosey and Paul Kirkham provide an analysis of "Research Opportunities Considering Student Entrepreneurship in University Eco-systems." And Rati Ram, Devrim Göktepe-Hultén, and Rajeev Goel, in Chapter 11, propose a research agenda in "Entrepreneurial Leadership in the Academic Community: A Suggested Research Agenda."

The volume concludes with three provocative essays that reflect the undertones of the previous chapters. In Chapter 12, Friederike Welter offers a thoughtful analysis, "The Power of Words and Images - Towards Talking About and Seeing Entrepreneurship and Innovation Differently." In Chapter 13, "Artificial Intelligence and Entrepreneurship: Some Thoughts for Entrepreneurship Researchers," Sameeksha Desai discusses the nexus between artificial intelligence and entrepreneurship/innovation. Finally, an appropriate conclusion to this volume comes in Chapter 14, by Mark Casson, "Entrepreneurship Studies: The Case for Radical Change," in which he calls for radical changes in how entrepreneurship is studied.

Entrepreneurship and innovation have attracted considerable attention from both the research community as well as thought leaders in public policy and business. The contents contained in the subsequent chapters of this book promise a rich and fertile research field with diverse perspectives building upon multiple academic fields and disciplines. We look forward to seeing how these promises of research are actualized in the coming years.

\section{References}

Chandler, Alfred, 1990, Scale and Scope: The Dynamics of Industrial Capitalism. Cambridge: Harvard University Press.

Link, Albert N., 2017, "Ideation, Entrepreneurship and Innovation," Small Business Economics: An Entrepreneurship Journal, 48 (2), 279-85.

Romer, Paul, 1986, “Increasing Returns and Long-Run Growth,” Journal of Political Economy, 94 (5), $1002-37$.

Solow, Robert, 1956, “A Contribution to the Theory of Economic Growth," Quarterly Journal of Economics, 39, 312-20. 